\title{
New records of Funalia trogii, Perenniporia tenuis and Polyporus pseudobetulinus from Finland, with notes on their habitat requirements and conservation implications
}

\author{
PETRI MARTIKAINEN, REIJO PENTTILÄ, HEIKKI KOTIRANTA and OTTO MIETTINEN
}

\begin{abstract}
MARTIKAINEN, P., PENTTILÄ, R., KOTIRANTA, H. \& MIETTINEN, O. 2000: New records of Funalia trogii, Perenniporia tenuis and Polyporus pseudobetulinus from Finland, with notes on their habitat requirements and conservation implications. Karstenia 40: 79-92. Helsinki. ISSN 0453-3402.

We report the results of three extensive surveys between 1996 and 1999 on the polypore flora of dead aspen trees (Populus tremula L.) in eastern Finland. These surveys yielded several new finds and new information on the habitat requirements of three polypore species classified as endangered in Finland: Funalia trogii (Berk.) Bondartsev \& Singer, Perenniporia tenuis (Schwein.) Ryvarden and Polyporus pseudobetulinus (Pilát) Thorn, Kotir. \& Niemelä. Our observations confirm that $F$. trogii is a thermophile preferring sun-exposed habitats. Similarly, all new records of $P$. tenuis were made in open habitats. $P$. pseudobetulinus has also been found occasionally on retained aspens in clear-cut areas, although it is usually located in old-growth forests. Our results suggest that these and other threatened species with similar habitat requirements could possibly survive even in a managed forest landscape, provided that potential host trees are retained in sufficient numbers. Most of the new records derive from trees killed by notching or girdling, indicating that suitable host trees for these species can be created even by killing trees. However, notching or girdling should be used with caution because it will reduce the availability of aspen trees in the future.
\end{abstract}

Key words: aspen, conservation implications, Funalia trogii, habitat ecology, Perenniporia tenuis, Polyporus pseudobetulinus, threatened polypores

Petri Martikainen, University of Joensuu, Faculty of Forestry, P.O.Box 111, FIN80101 Joensuu, Finland. E-mail: petri.martikainen@joensuu.fi

Reijo Penttilä, Research Centre of Friendship Park, Tönölä, FIN-88900 Kuhmo, Finland, and Department of Ecology and Systematics, Division of Systematic Biology, P.O.Box 47, FIN-00014 University of Helsinki, Finland. E-mail: reijo.penttila@kai.inet.fi

Heikki Kotiranta, Finnish Environment Institute, Nature and Land Use Division, P.O.Box 140, FIN-00251 Helsinki, Finland.E-mail: heikki.kotiranta@vyh.fi

Otto Miettinen, Department of Ecology and Systematics, Division of Systematic Biology, P.O.Box 47, FIN-00014 University of Helsinki, Finland. E-mail: OM@sll.fi

\section{Introduction}

Funalia trogii (Berk.) Bondartsev \& Singer, Perenniporia tenuis (Schwein.) Ryvarden and Polyporus pseudobetulinus (Pilát) Thorn, Kotir. \& Niemelä, are rare polypore species seldom found in Europe and there are only a few records of their existence in the Nordic countries (Niemelä et al. 1992, Ryvarden \& Gilbertson 1993, 1994, Olofsson 1996). All of these species are classified as 
endangered in Finland (Rassi et al. 1992, Kotiranta \& Niemelä 1996) and almost all records in the Nordic countries derive from aspen trees (Populus tremula L.). Aspen trees, especially large living trees, snags and logs, are an important host for hole-nesting birds (Hågvar et al. 1990), invertebrates (Siitonen \& Martikainen 1994, Siitonen 1999), wood-rotting fungi (Kotiranta \& Niemelä 1996), bryophytes (Andersson \& Hytteborn 1991, Kuusinen 1996) and lichens (Kuusinen 1994, 1995).

The first record of Funalia trogii in Finland was made in 1988 in Ilomantsi, eastern Finland (Niemelä et al. 1992). It was rediscovered in 1992 at the same site, but until now there have been no other records from the country. P. tenuis has been recorded twice in Finland: Etelä-Häme, Tammela, in 1879 on Alnus incana (L.) Moench and Pohjois-Karjala, Lieksa, Patvinsuo National Park in 1989 on aspen (Niemelä et al. 1992). P. pseudobetulinus is a very rare species all throughout the world (Thorn et al. 1990). In Finland it was known for a long time at two sites: Pohjois-Häme, Karstula (1956), and a viable population from north-western Finland in PeräPohjanmaa, Rovaniemi municipality and Tervo1a, Pisavaara Strict Nature Reserve (Kotiranta \& Niemelä 1996). During the 1990s it was intensively sought in extensive surveys of old-growth forests (The Old Forest Inventory Programme) and by 1996, it had been spotted 25 times (Kotiranta \& Niemelä 1996). After 1996, it was discovered in at least 15 new localities in Finland.

The taxonomy of these three species has been discussed by Thorn et al. (1990) and Niemelä et al. (1992). Here, we compile new records of Funalia trogii, Perenniporia. tenuis and Polyporus pseudobetulinus from Finland together with information on accompanying species. We provide up-to-date distribution maps for these three species as well new information on their habitat requirements, and discuss the implications for their conservation.

\section{Materials and methods}

Most of the new finds derive from two intensively studied areas and three independent inventories. In addition, some scattered records from other areas are included. The material is preserved in the herbaria $\mathrm{H}, \mathrm{HPP}$, JYV and OULU (Holmgren et al. 1990) and/or reference collections of Heikki Kotiranta (H.K.), Harri Lappalainen (H.L.), Otto Miettinen (O.M.), Tuomo Niemelä (T.N.), Reijo Penttilä (R.P.) and Pertti Renvall (P.R.). We use the biological provinces of Finland, and indicate the collecting sites according to the Finnish national uniform grid system (Grid $27^{\circ} \mathrm{E}$; Heikinheimo \& Raatikainen 1981). In the distribution maps every dot covers $10 \times 10$ $\mathrm{km}$ and can thus include either one or several separate patches where the fungus is found. The nomenclature of accompanying fungal species follows Niemelä (1999; polypores) and Hjortstam (1984; corticioid fungi). The authors of the species are cited in those publications and are not repeated in the text.

Habitat notes of $F$. trogii and $P$. tenuis derive from our own records, but for $P$. pseudobetulinus information from other adequate records (i.e., containing more datiled information on habitats) was used as well.

\section{Study areas and inventories}

Savonranta: The study area is situated in the biological province Pohjois-Savo, in eastern Finland, and belongs to the southern boreal subzone (Ahti et al. 1968). The records in Savonranta were made during a survey of polypore flora on fallen aspen trunks, conducted by P.M. and R.P. in 1996-97. Over 100 fallen trunks of aspen were examined in two localities: Raatelamminsalo (6908:602) and Muhamäki (6910:604).

The old-growth forest reserve "Raatelamminsalo" is one of the most outstanding examples of aspen-rich oldgrowth forests in southern Finland; some aspens reach a diameter of $90 \mathrm{~cm}$ and a height of over $30 \mathrm{~m}$. The size of the reserve is 69 ha, of which about 10 ha had been clearcut during the winter of 1991-92. Most of the aspens (over 200) in the clear-cut area had been left standing, but many of them had fallen soon after cutting (Fig. 2).

The old-growth reserve "Muhamäki" is 55 ha in size, of which 10 ha was clear-cut in 1984. Practically all aspens were notched (killed with herbicides) one year before the clear-cutting. Later, almost every tree had lost its bark and fallen (Fig. 5). The area has been replanted with pine.

Kuhmo - Sotkamo: The study area is situated in the province Kainuu in eastern Finland ca. $300 \mathrm{~km}$ north of Savonranta and belongs to the middle boreal subzone (Ahti et al. 1968). An extensive inventory of living and dead aspen trees and goat willows (Salix caprea L.), and three polypore (including $\mathrm{P}$. pseudobetulinus) and one lichen species associated with these tree species, took place during the years 1997-1999, and covered 100 $\mathrm{km}^{2}$. The total number of aspen trees studied (DBH $>15$ $\mathrm{cm}$ ) was almost 35000 (see Gu et al. 2000).

The southern part of the study area is dominated by old-growth spruce forests and large old aspens are common in the area. Only a small proportion of the aspens have been purposefully killed, and the area is much less influenced by forest management than the northern part of the study area, where the proportion of oldgrowth forest is lower and the old-growth forests are more fragmented.

Another study of polypores on dead aspens was carried out by the author O.M. in 1998 in Kuhmo, in the large aspen and goat willow inventory area. The survey covered $9 \mathrm{~km}^{2}: 3 \mathrm{~km}^{2}$ was aspen-rich old-growth forest and $6 \mathrm{~km}^{2}$ was managed landscape with more scattered occurrence of aspen. 


\section{Results}

Funalia trogii: Seven of the new $F$. trogii records were made in Savonranta and one in Kuhmo (Appendix). All the records of $F$. trogii in this study (as well as the first record from Fin- land; Niemelä et al. 1992) are from thick (mean $\mathrm{DBH}=41 \mathrm{~cm}$ ) aspen trunks lying in sun-exposed locations (Table 1, Figs. 1,2). Although we examined the same number of similar aspen trunks in old-growth forests as counted in clear-cuts in Savonranta, we did not find the species inside

Table 1. Characteristics of host trees and forest habitats inhabited by Funalia trogii.

\begin{tabular}{cccccccc}
\hline Tree no & Habitat & Quality & Treatment & DBH $(\mathrm{cm})^{\mathrm{a}}$ & $\begin{array}{c}\text { Decay } \\
\text { stage }(1-5)^{\mathrm{b}}\end{array}$ & $\begin{array}{c}\text { Bark } \\
\text { Coverage (\%) }\end{array}$ & $\begin{array}{c}\text { Fruitbody } \\
\text { condition }\end{array}$ \\
\hline 1 & clear-cut & fallen trunk & no & 60 & 3 & 50 & mostly dead \\
2 & clear-cut & fallen trunk & no & 41 & 1 & 80 & young, alive \\
3 & clear-cut & fallen trunk & no & 45 & 1 & 80 & young, alive \\
4 & sapling stand & fallen trunk & cut & 30 & 3 & 0 & mostly dead \\
5 & sapling stand & fallen trunk & notched & 42 & 3 & 30 & dead \\
6 & sapling stand & fallen trunk & notched & 44 & 3 & 30 & dead \\
7 & sapling stand & fallen trunk & notched & 40 & 3 & 30 & dead \\
8 & sapling stand & fallen trunk & $-^{c}$ & 26 & 3 & 70 & 44 \\
\hline Mean
\end{tabular}

${ }^{a}$ Diameter at breast height.

${ }^{\mathrm{b}}$ Dominant decay stage in the host tree. For a description of different decay stages see Renvall (1995).

${ }^{\mathrm{c}}$ Data missing.

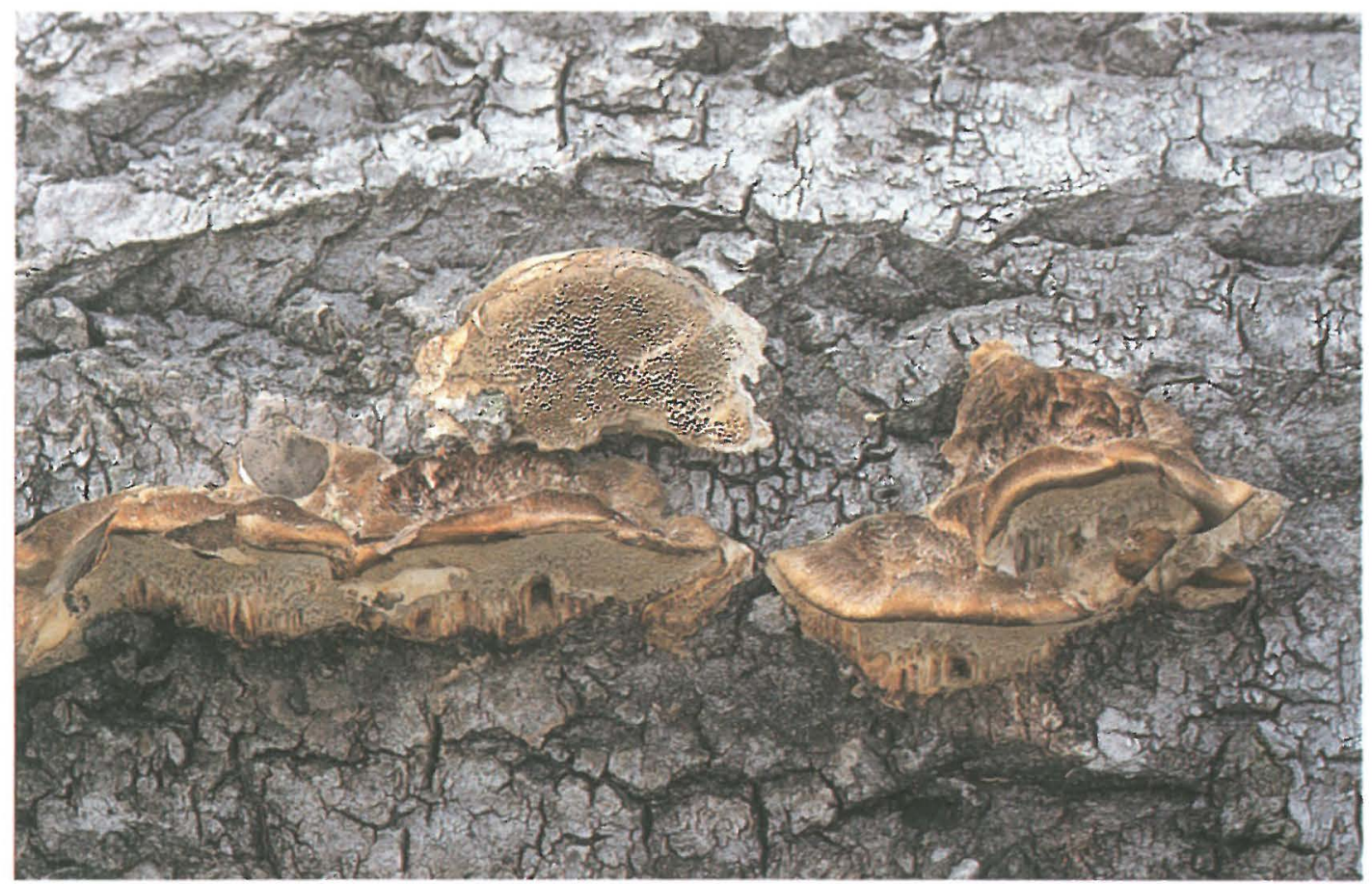

Fig. 1. Fruit body of Funalia trogii on a fallen aspen. Raatelamminsalo, Savonranta. Photo P. Martikainen. 


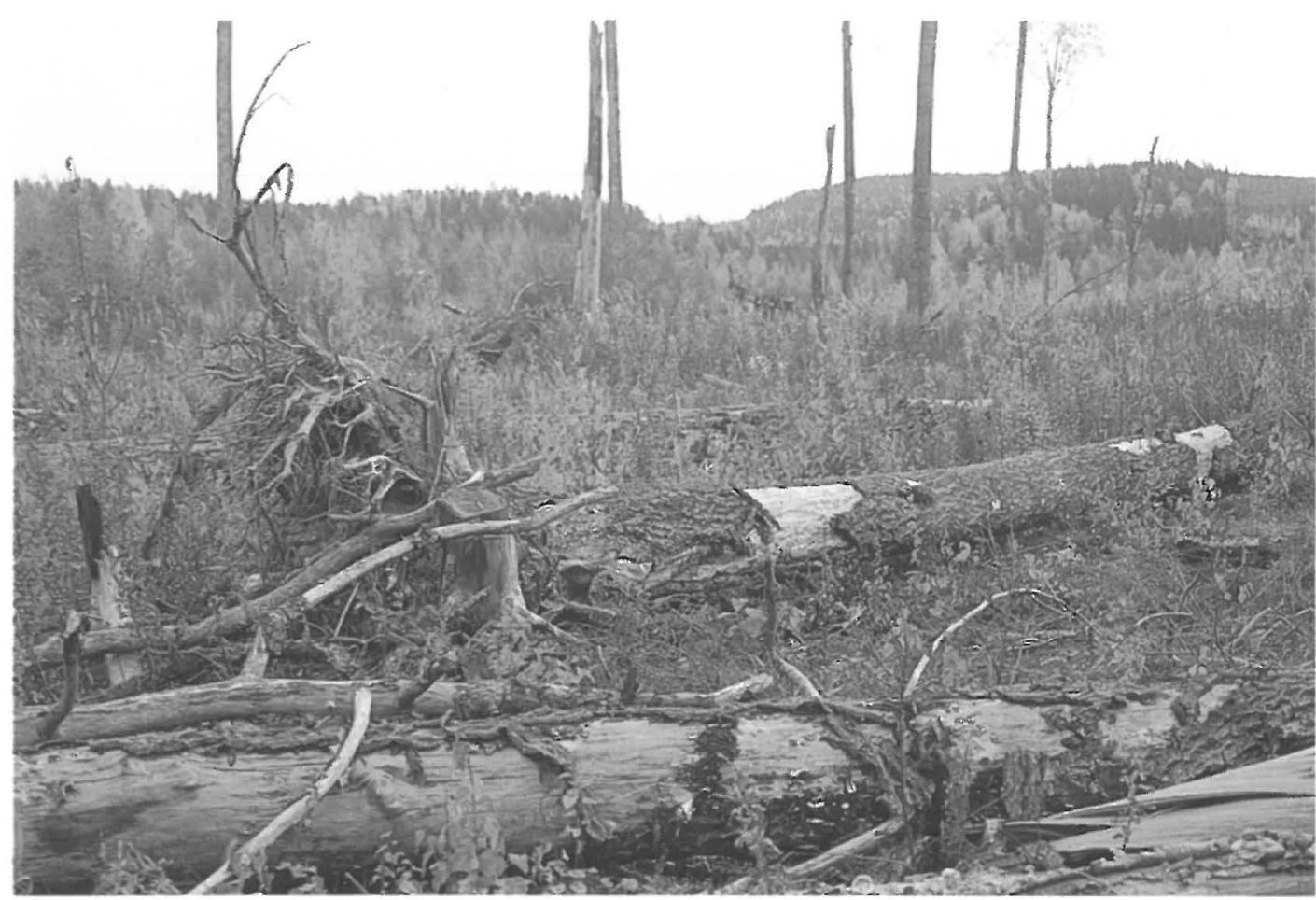

Fig. 2. Habitat of Funalia trogii in Raatelamminsalo, Savonranta. The more distant fallen trunk in the front hosted several young fruit bodies of the species. Photo P. Martikainen 1996.

the forest. In Kuhmo, hundreds of fallen aspen trunks were examined both inside and outside old-growth forests and $F$. trogii was found only from an open sapling stand. Half of the records were also from purposefully killed trees (Table 1).

Funalia trogii seems to favour fresh, only slightly decayed trunks: in Savonranta vigorously growing fruit bodies were observed as early as four years after the tree had fallen (trunks with decay stage 1; Table 1). Conversely, nearly all of the fruit bodies found on trunks that were notched in 1983, were dead in 1997 (trunks with decay stage 3; Table 1). Trametes ochraceae, Bjerkandera adusta and Gloeophyllum sepiarium, which are the most frequent accompanying species (Table 4), are also known to start producing fruitbodies at an early stage of wood decomposition.

Perenniporia tenuis: P. tenuis was found three times in Kuhmo, once in Muhamäki, Savonranta and once in Pampalo, Ilomantsi (Appendix). All these records were made in open clear-cut or sapling areas (Table 2, Fig. 4). All the records, except one, were also made in aspen-rich spots, where dead trunks were more common than in the surrounding landscape.

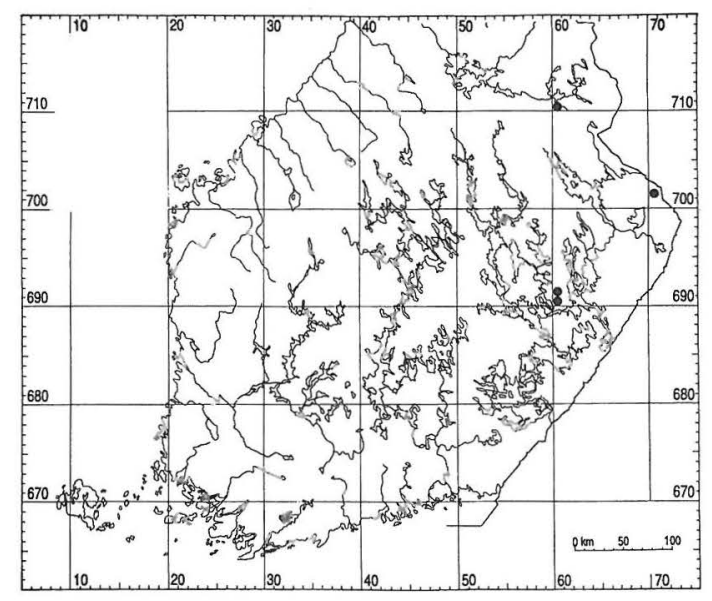

Fig. 3. Distribution of Funalia trogii in Finland. 
Table 2. Characteristics of host trees and forest habitats inhabited by Perenniporia tenuis.

\begin{tabular}{|c|c|c|c|c|c|c|c|}
\hline Tree no & Habitat & Quality & Treatment & DBH $(\mathrm{cm})^{\mathrm{a}}$ & $\begin{array}{c}\text { Decay } \\
\text { stage }(1-5)^{b}\end{array}$ & $\begin{array}{c}\text { Bark } \\
\text { Coverage (\%) }\end{array}$ & $\begin{array}{l}\text { Fruitbody } \\
\text { condition }\end{array}$ \\
\hline 1 & sapling stand & loose branch & notched & 6 & 2 & 0 & alive \\
\hline 2 & clear-cut & fallen trunk & notched & 50 & 3 & 0 & alive \\
\hline \multirow[t]{2}{*}{3} & sapling stand & piece of fallen & & & & & \\
\hline & & trunk & $-^{\mathrm{c}}$ & 15 & 3 & 0 & alive \\
\hline 4 & sapling stand & fallen trunk & girdled & 30 & 4 & 0 & alive \\
\hline 5 & sapling stand & fallen trunk & no & 19 & 3 & 0 & alive \\
\hline Mean & & & & 24 & & 0 & \\
\hline
\end{tabular}

a Diameter at breast height.

${ }^{b}$ Dominant decay stage in the host tree. For a description of different decay stages see Renvall (1995).

c Data missing.

Most of the records were from trees killed by notching or girdling. The size of the host tree is not as important for $P$. tenuis as for F. trogii, because it was found even from a separated branch (Figs 3, 4), and from both thin and thick trunks (mean DBH of host trees $=24 \mathrm{~cm}$; Table 2). $P$. tenuis prefers decorticated trees at rather advanced stages of decay (Table 2). The most frequent accompanying species was Gloeophyllum sepiarium (Table 4), a thermophilic species preferring open, sunny habitats.

Polyporus pseudobetulinus: The inventory in the Kuhmo and Sotkamo study area yielded several new records of $P$. pseudobetulinus. Although the southern part of the study area was thought to be most suitable for P. pseudobetuli$n u s$, it was found only in Heinävaara area, which belongs to the more managed northern part of the study area. The number of aspens is high in Heinävaara, but almost all of the trees have been killed by notching. In the inventory years 1998 and 1999, P. pseudobetulinus was found on 19 trees within an area of about $2 \mathrm{~km}^{2}$. This area contains now the richest known population of the species in Europe, and probably also worldwide (see Thorn et al. 1990). Almost all observations (17 of the 19 host trees) of P. pseudobetulinus in Heinävaara, Sotkamo were made on trees killed by notching. The richest occurrence ( 8 trees) was in fern-rich (Matteuccia struthiopteris (L.) Tod.), moist brookside, where the largest aspens were about $70-80 \mathrm{~cm}$ in diameter (Fig. 7). Other trees with $P$. pseudobetulinus were distributed in rather scattered fashion in the rest of the area. Most records were from small old-growth forest patches, but five were also from clear-cut areas.

The complete data set of habitat notes (Table 3) shows that $P$. pseudobetulinus prefers old- growth forests $(n=43)$. However, some records $(\mathrm{n}=11)$ derive from clear-cuts or sapling stands. The richest populations in Finland (Heinävaara and Pisavaara) are on rich, luxuriant sites dominated by spruce (see Fig. 7).

$P$. pseudobetulinus has principally been observed on dead trees $(n=42)$ - the species has been found only 10 times on living aspens (Table $3)$. Furthermore, many of the living trees were almost dead, which seems to indicate that $P$. pseudobetulinus is able to colonise only weakened or dead trees, or perhaps more likely, it only produces fruit bodies on such trees. It prefers large (mean $\mathrm{DBH}=38 \mathrm{~cm})$, standing trees or snags $(\mathrm{n}=$ 44). However, occasionally $(n=9)$ living fruit bodies were found on recently fallen trees and even on trees that had fallen several years earlier.

A large proportion of host trees were notched or girdled $(n=23)$, the remainder $(n=21)$ were alive or had died naturally (Table 3 ). Phellinus tremulae, a very common polypore species in mature aspens (Niemelä 1999), is the most frequent accompanying species ( $n=17 / 30$; Table 4). There were few other accompanying species, and on eight occasions no other species was found on the same tree.

\section{Discussion}

Habitat requirements: The preference of $F$. trogii for open habitats is well documented in the Finnish material. Furthermore, we found this species earlier under similar conditions in the Kivach Nature Reserve (Siitonen et al. 1996) and in the Vodlozersky National Park (Siitonen et al. 2000) in the Republic of Karelia, Russia. All of this confirms that $F$. trogii is a thermophilous species, as suggested by Kotiranta and Niemelä (1996). One 
Table 3. Characteristics of host trees and forest habitats inhabited by Polyporus pseudobetulinus.

\begin{tabular}{|c|c|c|c|c|c|}
\hline Tree no & Habitat & Quality & Condition & Treatment & $\mathrm{DBH}(\mathrm{cm})^{\mathrm{a}}$ \\
\hline 1 & old forest & standing tree & dead & $-{ }^{\mathrm{b}}$ & - \\
\hline 2 & old forest & standing tree & dead & - & - \\
\hline 3 & old forest & standing tree & dead & girdled & 20 \\
\hline 4 & old forest & standing tree & dead & girdled & 46 \\
\hline 5 & clear-cut & standing tree & dead & girdled & - \\
\hline 6 & clear-cut & standing tree & dead & girdled & - \\
\hline 7 & old forest & standing tree & dead & girdled & - \\
\hline 8 & old forest & standing tree & dead & - & - \\
\hline 9 & old forest & fallen trunk & dead & - & - \\
\hline 10 & clear-cut & snag & dead & notched & 31 \\
\hline 11 & clear-cut & snag & dead & notched & 28 \\
\hline 12 & clear-cut & snag & dead & notched & 20 \\
\hline 13 & clear-cut & fallen trunk & dead & notched & 18 \\
\hline 14 & old forest & standing tree & alive & no & 39 \\
\hline 15 & old forest & standing tree & dead & notched & 18 \\
\hline 16 & old forest & standing tree & dead & notched & 22 \\
\hline 17 & old forest & snag & dead & notched & 29 \\
\hline 18 & old forest & snag & dead & notched & 51 \\
\hline 19 & old forest & standing tree & dead & notched & 44 \\
\hline 20 & old forest & fallen trunk & dead & no & 26 \\
\hline 21 & old forest & fallen trunk & dead & notched & 25 \\
\hline 22 & old forest & fallen trunk & dead & notched & 30 \\
\hline 23 & old forest & standing tree & dead & notched & 32 \\
\hline 24 & old forest & standing tree & dead & notched & 12 \\
\hline 25 & old forest & standing tree & dead & notched & 30 \\
\hline 26 & old forest & fallen trunk & dead & notched & 34 \\
\hline 27 & clear-cut & fallen trunk & dead & girdled & 30 \\
\hline 28 & old forest & standing tree & dead & notched & 35 \\
\hline 29 & old forest & fallen trunk & dead & no & 27 \\
\hline 30 & old forest & standing tree & dead & no & 27 \\
\hline 31 & old forest & standing tree & alive & girdled & - \\
\hline 32 & old forest & snag & dead & - & - \\
\hline 33 & old forest & snag & dead & - & - \\
\hline 34 & old forest & standing tree & dead & no & 40 \\
\hline 35 & sapling stand & standing tree & dead & - & 38 \\
\hline 36 & old forest & standing tree & alive & - & 45 \\
\hline 37 & old forest & standing tree & dead & no & 35 \\
\hline 38 & old forest & standing tree & alive & no & 40 \\
\hline 39 & sapling stand & standing tree & dead & no & 45 \\
\hline 40 & old forest & - & - & - & - \\
\hline 41 & old forest & - & - & - & - \\
\hline 42 & clear-cut & standing tree & dead & no & - \\
\hline 43 & clear-cut & standing tree & dead & no & - \\
\hline 44 & old forest & standing tree & alive & no & 48 \\
\hline 45 & old forest & standing tree & dead & no & 64 \\
\hline 46 & old forest & standing tree & alive & no & 64 \\
\hline 47 & old forest & snag+fallen trunk & dead & no & 64 \\
\hline 48 & old forest & standing tree & alive & no & 54 \\
\hline 49 & old forest & standing tree & alive & no & 41 \\
\hline 50 & old forest & standing tree & alive & no & 48 \\
\hline 51 & old forest & standing tree & alive & no & 67 \\
\hline 52 & old forest & standing tree & dead & no & 62 \\
\hline 53 & old forest & standing tree & dead & no & 64 \\
\hline 54 & old forest & standing tree & dead & no & 22 \\
\hline TOTAL & $\begin{array}{c}\text { old forest } 43 \\
\text { clear-cut } 9 \\
\text { sapling stand } 2\end{array}$ & $\begin{array}{l}\text { standing tree } \\
\text { or snag } 44 \\
\text { fallen trunk } 9\end{array}$ & $\begin{array}{l}\text { dead } 42 \\
\text { alive } 10\end{array}$ & $\begin{array}{c}\text { notched or } \\
\text { girdled } 23 \\
\text { no treatment } 21\end{array}$ & mean DBH $38 \mathrm{~cm}$ \\
\hline
\end{tabular}

a Diameter at breast height.

${ }^{\mathrm{b}}$ Data missing. 


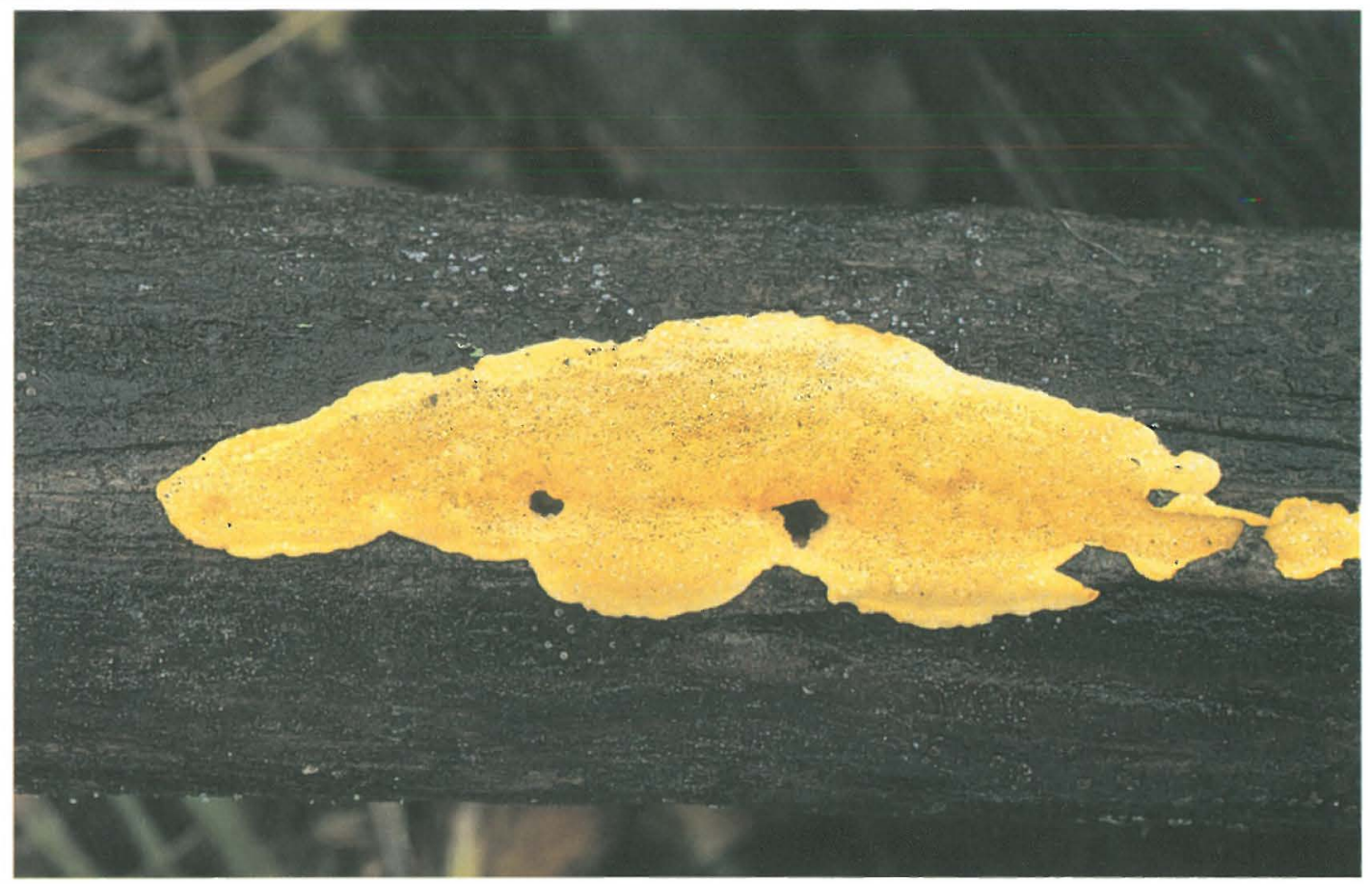

Fig. 4. Bright yellow fruit body of Perenniporia tenuis on decorticated, thin branch of aspen. Muhamäki, Savonranta. Photo R. Penttilä 1997.

of the most frequently accompanying species was Gloeophyllum sepiarium, which also prefers open habitats, such as clear-cuts (Niemelä 1999) and burned areas (Penttilä \& Kotiranta 1996). The information on the habitat requirements of $F$. trogii in northern China (Dai 1996), Siberia, Irkutsk Region and Russian Far East, Magadan Region (Kotiranta, unpublished) corresponds with our data. In those areas, $F$. trogii is mostly found in standing trees, fallen trunks and stumps of $P$ opulus or Salix on open, sunny sites. In northern China it also seems to prefer fresh wood as it was often found on freshly cut logs and stumps.

An important reason for the rarity of $F$. trogii in Nordic countries is evidently the lack of suitable hosts (large aspen trunks in open places) in managed and even in protected forests (Siitonen \& Martikainen 1994, Linder et al. 1997, Östlund et al. 1997, Martikainen 2000). The species is found here also at the western and northern limits of its distributional range. F. trogii is widespread in warmer parts of Europe (Ryvarden \& Gilbertson 1993) and seems to be more common in central, southern and Eastern Europe than in the Nordic countries (Niemelä et al. 1992). In northern China (Dai 1996), Siberia and Russian Far East (Kotiranta, unpublished), it is rather common. This may indicate that the climate in Nordic countries is not favourable (i.e. warm and continental enough) for F. trogii.

The new records of $P$. tenuis from clear-cuts and sapling stands are surprising, as the previous record from 1989 was made in an old-growth forest. For instance, Kotiranta and Niemelä (1996) assumed that this species would require undisturbed, moist and shaded conditions. Our observations suggest that factors other than microclimate are important for the survival of this species. However, $P$. tenuis probably needs more moisture in its habitat than $F$. trogii does as most records in Finland are from trees lying on rather moist ground.

Strict habitat requirements do not seem to explain the rarity of $P$. tenuis; other reasons for its rarity may be poor competitive ability or problems in dispersal and colonisation. Dispersal problems could be the best explanation because almost all finds from Finland are from aspen-rich 


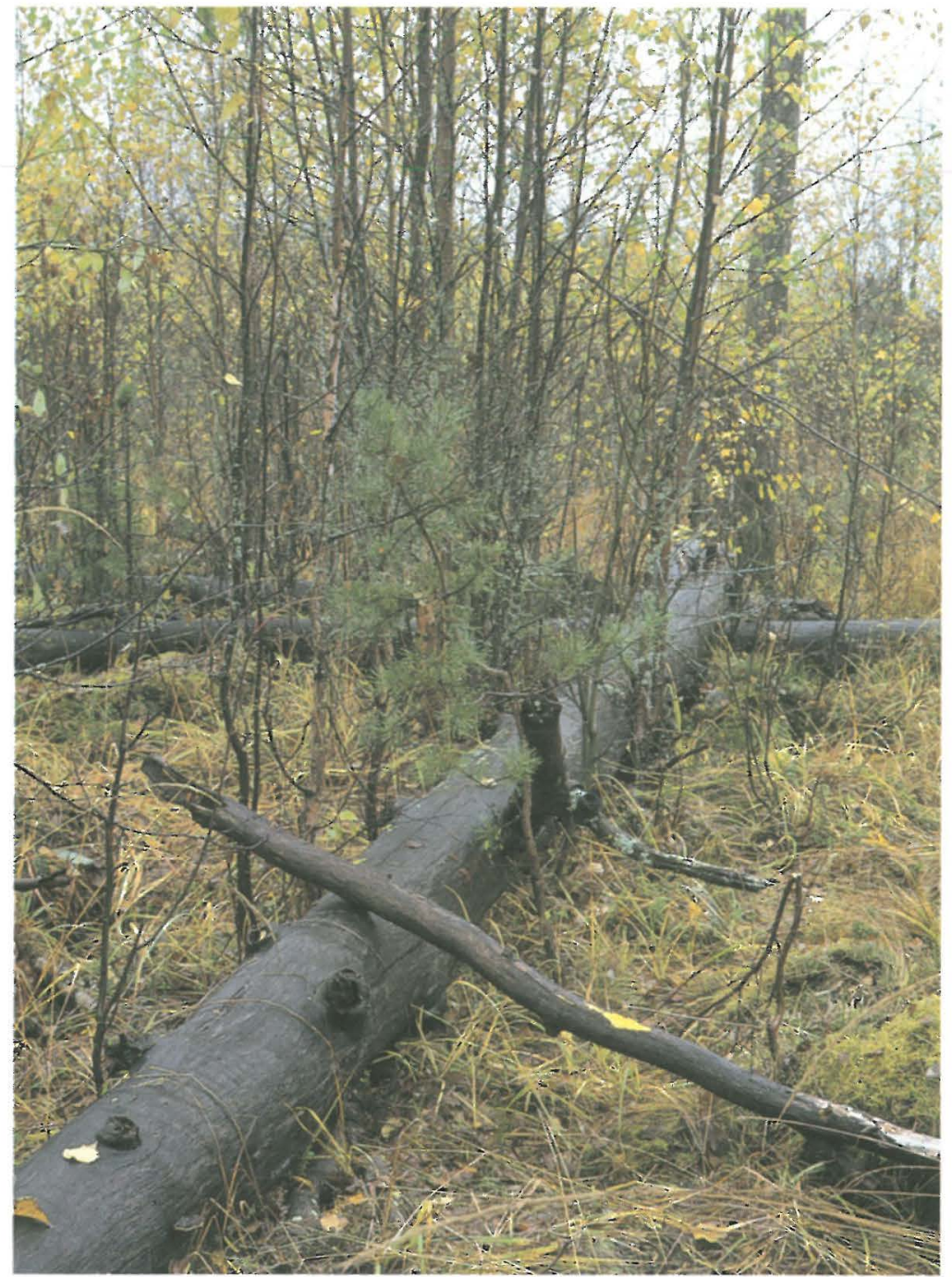

Fig. 5. The habitat, 13 years old clear-cut, of Perenniporia tenuis in Muhamäki, Savonranta. The separated branch containing the fruit body of the species leaning towards its host tree. Photo R. Penttilä 1997. "hot spots" where the availability and continuity of suitable host trees is very good. Muhamäki in Savonranta is an example of such a "hot spot", as indicated by the exceptionally rich fauna of saproxylic beetles living on aspen in that region (Rutanen 1995, Martikainen 2000). Besides P. tenuis and $F$. trogii, several threatened fungi in Finland, such as Antrodia pulvinascens, Gelatoporia pannocincta, Protomerulius caryae, Radulodon erikssonii, Scytinostroma galactinum and Skeletocutis odora were found on only 22 trunks in the Muhamäki clear-cut, giving additional support for the long substrate continuity in the area.
Of the three species studied, P. pseudobetulinus is most strongly associated with old-growth forests. However, even this view may be erroneous, since large, old aspens are mainly located in old-growth reserves and such trees are usually absent in managed forests ( Siitonen \& Martikainen 1994, Hazell 1999). In old forests, P. pseudobetulinus seems to prefer rather open habitats (Thorn et al. 1990, Olofsson 1996) and on a few occasions it has been found on trees left in clearcut areas. Consequently, if more suitable host trees were available in managed forests, $P$. pseudobetulinus could possibly be maintained also in managed forest landscape. Another reason for 
Table 4. Accompanying species in trees inhabited by Funalia trogii ${ }^{\mathrm{a}}(\mathrm{n}=8)$, Perenniporia tenuis ${ }^{\mathrm{b}}(\mathrm{n}=5)$ and Polyporus pseudobetulinus ${ }^{\mathrm{C}}(\mathrm{n}=30)$.

\begin{tabular}{lccc}
\hline Species & Frequency & Frequency $^{\mathrm{b}}$ & Frequency $^{\mathrm{c}}$ \\
\hline Antrodiella semisupina & 1 & - & - \\
Armillaria borealis & - & - & 1 \\
Bjerkandera adusta & 4 & - & 3 \\
Ceriporia viridans & 1 & - & - \\
Chondrostereum purpureum & 1 & - & 3 \\
Fomes fomentarius & 2 & - & - \\
Fomitopsis pinicola & 2 & - & 1 \\
Gelatoporia pannocincta & - & - & - \\
Gloeophyllum sepiarium & 5 & 3 & - \\
Hyphodontia aspera & - & 1 & - \\
Phellinus populicola & 1 & - & 17 \\
Phellinus tremulae & 2 & - & 3 \\
Phlebia fuscoatra & - & 1 & - \\
Pleurotus sp. & - & - & 2 \\
Polyporus brumalis & 1 & - & - \\
Polyporus leptocephalus & - & - & - \\
Postia alni & - & 2 & - \\
Postia tephroleuca & - & 1 & - \\
Postia undosa & - & 1 & 1 \\
Pycnoporus cinnabarinus & 1 & - & - \\
Rigidoporus corticola & 4 & - & - \\
Scytinostroma galactinum & - & 1 & 1 \\
Skeletocutis odora & - & 1 & 2 \\
Trametes hirsuta & - & - & - \\
Trametes ochraceae & 8 & 1 & - \\
Trametes sp. & - & 1 & \\
Tyromyces chioneus & 1 & - & \\
\hline & & & \\
\hline
\end{tabular}

its rarity could be that it seems to prefer rather fertile, productive habitats with large, old aspens (see Fig. 7); such habitats are very rare in managed forests.

The records of F. trogii, P. tenuis and P. pseudobetulinus [and of several other threatened species previously assumed to be old-growth forest specialists (Kotiranta \& Niemelä 1996)] from open areas suggest that many fungal species that preferentially live on aspens and other deciduous trees do not necessarily need the humid microclimate of an old-growth forest to survive. Aspen is an early-successional tree species and it used to be common in the deciduous phase following fire in the natural boreal and hemiboreal landscape (Hazell 1999). It is adapted to frequent disturbances caused by fire (Zackrisson 1985), and therefore it is likely that many species that preferentially live on aspen or other earlysuccessional deciduous tree species can survive frequent disturbances and are able to inhabit open areas. This hypothesis is supported also by recent studies on saproxylic beetles: a comparison between clear-cut areas and old-growth forests showed that the number and abundance of threatened beetles associated with dead aspen was actually higher on clear-cut areas (Martikainen 2000). Similarly, Kaila et al. (1997) found that several threatened saproxylic beetles could survive in open habitats. Moreover, Lobaria

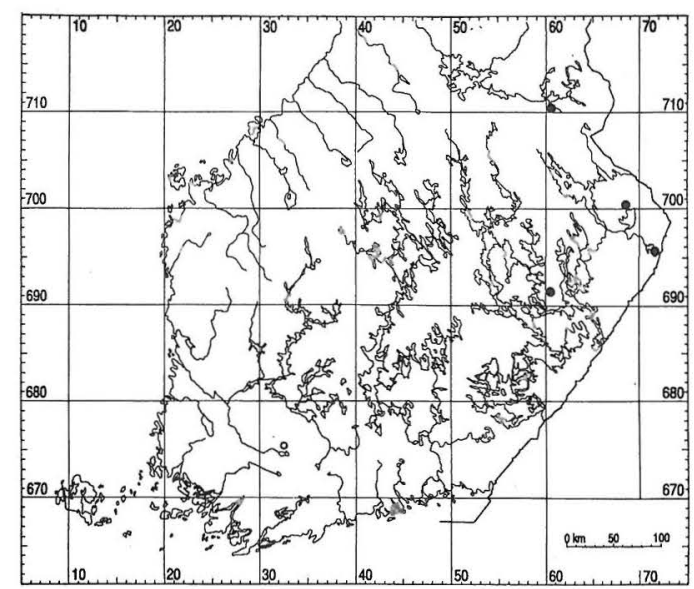

Fig. 6. Distribution of Perenniporia tenuis in Finland. (O - record made before 1960 , - record made after 1960). 


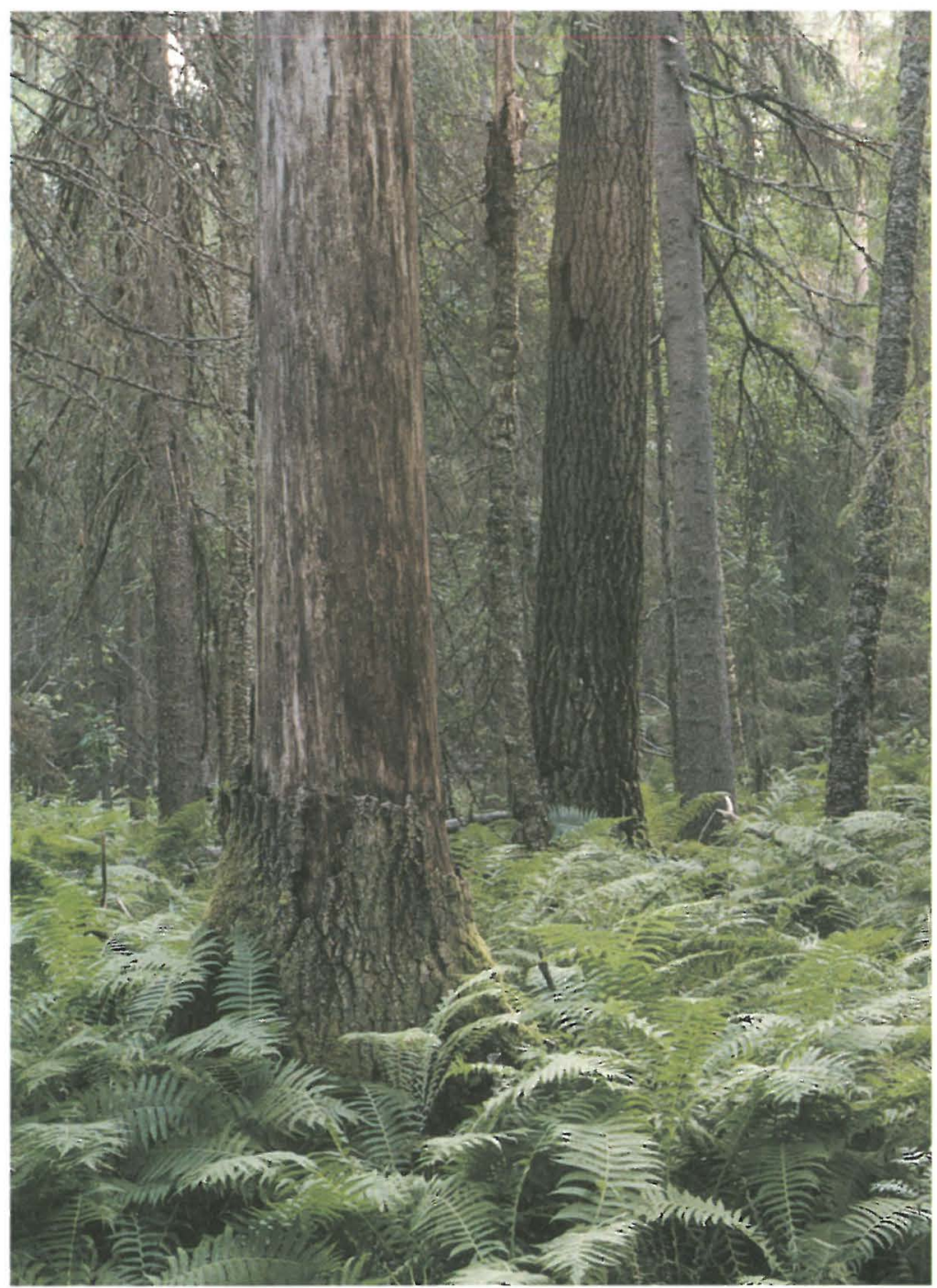

Fig. 7. Fernrich and moist habitat of Polyporus pseudobetulinus with large, notched aspens. Heinävaara, Sotkamo. Photo R. Penttilä 1997.. pulmonaria (L.) Hoffm., a lichen often used as an indicator of old-growth forests (Andersson \& Appelqvist 1987, Kuusinen 1994, 1996), may survive better in more open forests (or within groups of retained old trees in clear-cuts) than in old, shaded forests (Hazell \& Gustafsson 1999, Kuusinen, unpublished).

Conservation implications: There are at least three important reasons why the conservation of threatened species associated with aspen cannot be based solely on protection of old-growth forests in Finland. Firstly, several empirical and theoretical studies (see e.g. Andrén 1994, 1996,
With \& Crist 1995, Fahrig 1997, Hanski 1999, Virkkala \& Toivonen 1999) predict that when the size of an original habitat of a species decreases, for example, to the extent of old-growth forests in southern Finland, the probability of a species surviving in the long run is low. Secondly, the proportion of deciduous trees is likely to decrease in the existing forest reserves because major disturbances (such as forest fires), which are essential for the regeneration of pioneer tree species, are currently lacking in the reserves (Linder et al. 1997, Östlund et al. 1997). For example, young aspens are almost absent in the 
Raatelamminsalo and the Kotinen old-growth forests, which are among the most aspen-rich forest reserves in southern Finland (Kuusinen \& Penttinen 1999, Martikainen 2000). Thirdly, many species associated with aspen may actually prefer conditions that are rather different from those prevailing in shady old-growth forests (this study, Martikainen 2000).

Taken together this means that several complementary methods are needed for the successful conservation of species associated with aspen. Despite the limitations mentioned above, oldgrowth reserves are indispensable for many species, especially for those dependent on the specific microclimate or continuity of old-growth forests (Berg et al. 1994, 1995, Kotiranta \& Niemelä 1996). The fact that protected areas are often the only places where large, old aspens can be found in high numbers further emphasizes the role of oldgrowth forests in the preservation of threatened species. It is, however, important to ensure that aspens are also available in the area in the future, and here the surrounding forests may prove to be very important. As the regeneration of aspen may require controlled burning or even clear-cutting with green tree retention (Linder 1998, Hazell 1999), such actions should preferably be taken outside the core old-growth forest areas.

The protection of old forests is apparently not the best possible conservation strategy for threatened species such as $F$. trogii and $P$. tenuis, which can tolerate sun exposure or are even adapted to open habitats. Instead, their successful conservation may require suitable host trees being available in sufficient numbers in open areas (Martikainen 2000). A recommendation to leave live and dead aspens on clear-cuts is thus warranted for the survival of many species.

Dead aspen is suitable for each saproxylic species for only a limited number of years. For instance, in our study notched aspens that had been dead for more than ten years no longer seemed to be suitable for $F$. trogii. To survive in a certain region, the species should be able to colonise new trees at the same rate as it disappears from those trees that have become too decayed to be suitable habitats. Thus, although the widespread and intensive notching of aspen in eastern Finland in the 1970s and 1980s created many suitable habitats for threatened species, the positive impact of this activity remains temporary. All the trees treated died almost simulta-

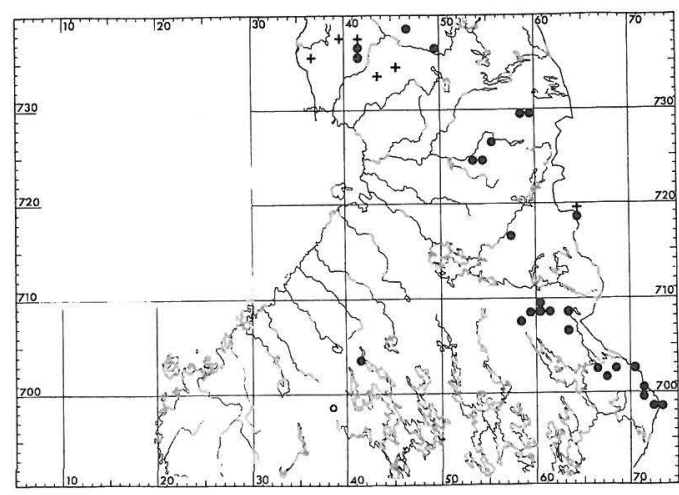

Fig. 8. Distribution of Polyporus pseudobetulinus in Finland. ( $O$ - record made before 1960 , - record made after $1960,+-$ record with no preserved specimens).

neously; thus the continuity of dying aspens will be interrupted for a long time. This was already visible in Muhamäki, where $F$. trogii seems to be disappearing and it will take at least 100 years until suitably large aspens are available at that site again. The same phenomenon is seen in Heinävaara, Sotkamo, where the abundant population of $P$. pseudobetulinus is in danger of disappearing, due to the lack of continuity of suitable host trees.

The girdling of aspen (bark is removed around the trunk) would probably be better than notching, if it is necessary to kill the trees that are retained on clear-cuts, because girdled trees take several years to die, and all of the trees do not always die at the same time (Aulén 1988, Siitonen \& Martikainen 1994). However, as is the case with notching, the continuity of new dead trees will be interrupted later on. Leaving at least part of the retained trees untreated would be a better option for the preservation of saproxylic species, as it is likely to maintain the continuity of dying trees at a particular site.

In many regions the future of rare aspen-specialists seems uncertain because new host trees are not becoming available at a sufficient rate. In such cases, the killing of aspen trees might be the best way to produce decaying wood that, according to our observations, would be suitable for many threatened species (see also Aulén 1988, Martikainen 2000). In some critical cases, it may even be necessary to transport fresh aspen logs to the target area. 
Acknowledgements: Work supported by: Academy of Finland (Projects 49025 and 10139457), Maj and Tor Nessling Foundation (Project 97076) and Finnish Forest and Park Service. We thank the staff of Research Centre of Friendship Park for carrying out the huge task in the aspen and goat willow inventory in Kuhmo and Sotkamo. Pehr Enckell, Mikko Kuusinen, Pertti Renvall and Orla Smith are thanked for making valuable comments to improve the manuscript. The English of this paper was revised by Michael Collinson.

\section{References}

Ahti, T., Hämet-Ahti, L. \& Jalas, J. 1968: Vegetation zones and their sections in northwestern Europe. Ann. Bot. Fennici 5: 169-211.

Andersson, L. \& Appelqvist, T. 1987: Lobaria pulmonaria and Gyalecta ulmi as indicators of deciduous woodland with high nature qualities. - Svensk Bot. Tidskr. 81: 185-194. (In Swedish with English summary).

Andersson, L. \& Hytteborn, H. 1991: Bryophytes and decaying wood: a comparison between managed and natural forest. - Holarctic Ecol. 14: 121-130.

Andrén, H. 1994: Effects of habitat fragmentation on birds and mammals in landscapes with different proportions of suitable habitat: a review. - Oikos 71: 355-366.

Andrén, H. 1996: Population responses to habitat fragmentation: statistical power and the random sample hypothesis. - Oikos 76: 235-242.

Aulén, G. 1988: Ecology and distribution history of the white-backed woodpecker Dendrocopos leucotus in Sweden. - Swedish Univ. Agric. Sci., Dept. Wildl. Ecol., Report 14. Uppsala, Sweden. 253 pp.

Berg, A.., Ehnström, B., Gustafsson, L., Hallingbäck, T., Jonsell, M. \& Weslien, J. 1994: Threatened plant, animal, and fungus species in Swedish forests: distribution and habitat associations. - Cons. Biol. 8: 718-731.

Berg, Å., Ehnström, B., Gustafsson, L., Hallingbäck, T., Jonsell, M. \& Weslien, J. 1995: Threat levels and threats to red-listed species in Swedish forests. Cons. Biol. 9: 1629-1633.

Dai, Y.C. 1996: Changbai wood-rotting fungi 7. A checklist of polypores. - Fungal Science 11: 79-105.

Fahrig, L. 1997: Relative effects of habitat loss and fragmentation on population extinction. - J. Wildl. Manage. 61: 603-610.

Gu, W.D., Kuusinen, M., Konttinen, T. \& Hanski, I. 2000: Spatial analysis of the lichen Lobaria pulmonaria in boreal forests. - Ecography (in press).

Hågvar, S., Hågvar, G. \& Mønnes, E. 1990: Nest site selection in Norwegian woodpeckers. - Holarctic Ecol. 13: 156-165.

Hanski, I. 1999: Metapopulation ecology. - Oxford University Press, Oxford. 313 pp.

Hazell, P. 1999: Conservation and yield aspects of old European aspen Populus tremula L. in Swedish forestry. - Acta Univ. Agric. Suec., Silvestria 102: 1-34 pp.

Hazell, P. \& Gustafsson, L. 1999: Retention of trees at final harvest-evaluation of a conservation technique using epiphytic bryophyte and lichen transplants. Biol. Cons. 90: 133-142.

Heikinheimo, O. \& Raatikainen, M. 1981: Ruutukoordinaattien ja paikannimien käyttö Suomessa. - Notulae Entomologicae 61: 133-154.

Hjortstam, K. 1984: Corticiaceous fungi of northern Europe - check-list of the species in the Nordic countries. - Windahlia 16: 1-29.

Holmgren, P.K, Holmgren, N.H. \& Barnett, L.C. (eds.) 1990: Index herbariorum. Part I. The herbaria of the world. Ed. 8. - Regnum Vegetabile 120: 1-693.

Kaila, L., Martikainen, P. \& Punttila, P. 1997: Dead trees left in clear-cuts benefit saproxylic Coleoptera adapted to natural disturbances in boreal forest. Biodiv. Cons. 6: 1-18.

Kotiranta, H. \& Niemelä, T. 1996: Uhanalaiset käävät Suomessa. Threatened polypores in Finland. Second revised edition. (In Finnish with English summary.) Ympäristöopas 10: 1-184. Suomen ympäristökeskus, Edita, Helsinki.

Kuusinen, M. 1994: Epiphytic lichen flora and diversity on Populus tremula in old-growth and managed forests of southern and middle boreal Finland. - Ann. Bot. Fennici 31: 245-260.

Kuusinen, M. 1995: Cyanobacterial macrolichens on Populus tremula as indicators of forest continuity in Finland. - Biol. Cons. 75: 43-49.

Kuusinen, M. 1996: Epiphyte flora and diversity on six common old-growth forest tree species in southern and middle boreal Finland. - Lichenologist 28: 443 463.

Kuusinen, M. \& Penttinen, A. 1999: Spatial pattern of the threatened epiphytic bryophyte Neckera pennata at two scales in a fragmented boreal forest. - Ecography 22: 729-736.

Linder, P. 1998: Stand structure and successional trends in forest reserves in boreal Sweden. - Acta Univ. Agric. Suec., Silvestria 72: 1-39 pp.

Linder, P., Elfving, B. \& Zackrisson, O. 1997: Stand structure and successional trends in virgin boreal forest reserves in Sweden. - For. Ecol. Manage 98: 1733.

Martikainen, P. 2000: Conservation of threatened saproxylic beetles: significance of retained aspen Populus tremula on clearcut areas. - Ecol. Bull. (in press).

Niemelä, T. 1999: Suomen kääpien määritysopas. Guide to the polypores of Finland. 12th revised edition. (In Finnish with English abstract and an identification key). - Bot. Bull. Univ. Helsinki 169: 1-138.

Niemelä, T., Kotiranta, H. \& Penttilä, R. 1992: New records of rare and threatened polypores in Finland. Karstenia 32: 81-94.

Olofsson, D. 1996: Tickor i Sverige. - Projektrapport 1996. WWF. 127 pp.

Östlund, L., Zackrisson, O. \& Axelsson, A-L. 1997: The history and transformation of a Scandinavian boreal forest landscape since the $19^{\text {th }}$ century. - Can. J. For. Res. 27: 1198-1206.

Penttilä, R. \& Kotiranta, H. 1996: Short-term effects of prescribed burning on wood-rotting fungi. - Silva Fennica 30: 399-419.

Rassi, P., Kaipiainen, H., Mannerkoski, I. \& Ståhls, G. 1992: Uhanalaisten eläinten ja kasvien seuranta- 
toimikunnan mietintö. - Komiteanmietintö 1991(30): 1-328. Ympäristöministeriö, Helsinki.

Renvall, P. 1995: Community structure and dynamics of wood-rotting fungi on decomposing conifer trunks in northern Finland. - Karstenia 35: 1-51.

Rutanen, I. 1995: Etelä-Suomen vanhojen metsien kovakuoriaiset II. Summary: Beetles of the old forests in South-Finland II. - Publ. Wat. Env. Adm. Ser. A 215: 1-76. National Boards of Waters and the Environment, Helsinki, Finland.

Ryvarden, L. \& Gilbertson, R.L. 1993: European polypores 1. Abortiporus-Lindtneria. - Synopsis Fungorum 6: 1-387. Fungiflora, Oslo.

Ryvarden, L. \& Gilbertson, R.L. 1994: European polypores 2. Meripilus-Tyromyces. - Synopsis Fungorum 7: 388-743. Fungiflora, Oslo.

Siitonen, J. 1999: Haavan merkitys metsäluonnon monimuotoisuudelle. - Metsäntutkimuslaitoksen tiedonantoja 725: 71-82.

Siitonen, J. \& Martikainen, P. 1994: Occurrence of rare and threatened insects living on decaying Populus tremula: a comparison between Finnish and Russian Karelia. - Scand. J. For. Res. 9: 185-191.
Siitonen, J., Martikainen, P., Kaila, L., Mannerkoski, I., Rassi, P. \& Rutanen, I. 1996: New faunistic records of threatened saproxylic Coleoptera, Diptera, Heteroptera, Homoptera and Lepidoptera from the Republic of Karelia, Russia. - Entomol. Fennica 7: 69-76.

Siitonen, J., Penttilä, R. \& Kotiranta, H. 2000: Coarse woody debris, polyporous fungi and saproxylic insects in an old-growth spruce forest in Vodlozero National Park, Russian Karelia. - Ecol. Bull. (in press).

Thorn, G., Kotiranta, H. \& Niemelä, T. 1990: Polyporus pseudobetulinus comb. nov.: New records in Europe and North America. - Mycologia 82: 582-594.

Virkkala, R. \& Toivonen, H. 1999: Maintaining biological diversity in Finnish forests. - Finnish Environment 278: 1-50. Finnish Environment Institute, Helsinki.

With, K.A. \& Crist, T.O. 1995: Critical thresholds in species' responses to landscape structure. - Ecology 76: $2446-2459$.

Zackrisson, O. 1985: Some evolutionary aspects of life history characteristics of broadleaved tree species found in boreal forest. - Dept. Silvic., Swedish Univ. Agric. Sci. Umeå. Report 14: 17-36.

Appendix. Collecting sites, dates, collectors and preserved specimens of the records of Funalia trogii, Perenniporia tenuis and Polyporus pseudobetulinus used in Tables 1,2 and 3. Tree numbers as in Tables 1, 2 and 3.

\section{Funalia trogii}

\begin{tabular}{cccccc}
\hline Tree no & Collecting site & Coordinate & Collecting date & Collectors & $\begin{array}{c}\text { Preserved } \\
\text { specimens }\end{array}$ \\
\hline 1 & PS: Savonranta, Raatelamminsalo & $6908: 602$ & 30. VIII.1996 & Martikainen, Penttilä & no \\
2 & PS: Savonranta, Raatelamminsalo & $6908: 602$ & 30. VIII.1996 & Martikainen, Penttilä & no \\
3 & PS: Savonranta, Raatelamminsalo & $6908: 602$ & 30. VIII.1996 & Martikainen, Penttilä & R.P. 11137 \\
4 & PS: Savonranta, Muhamäki & $6910: 604$ & 30. VIII.1996 & Martikainen, Penttilä & no \\
5 & PS: Savonranta, Muhamäki & $6910: 604$ & $11 . X .1997$ & Martikainen, Penttilä & R.P. 11730 \\
6 & PS: Savonranta, Muhamäki & $6910: 604$ & $11 . X .1997$ & Martikainen, Penttilä & R.P. 11733 \\
7 & PS: Savonranta, Muhamäki & $6910: 604$ & $11 . X .1997$ & Martikainen, Penttilä & no \\
8 & Kn: Kuhmo, Jauhovaara & $7102: 603$ & $17 . I X .1998$ & Miettinen & O.M. 451 \\
\hline
\end{tabular}

\section{Perenniporia tenuis}

\begin{tabular}{cccccc}
\hline Tree no & Collecting site & Coordinate & Collecting date & Collectors & $\begin{array}{c}\text { Preserved } \\
\text { specimens }\end{array}$ \\
\hline 1 & PS: Savonranta, Muhamäki & $6910: 604$ & $11 . X .1997$ & Martikainen, Penttilä & R.P. 11786 \\
2 & PK: Ilomantsi, Pampalo & $6995: 714$ & $23 . I X .1998$ & Martikainen, Lappalainen & H.L., P.R. \\
3 & Kn: Kuhmo, Jauhovaara & $7102: 604$ & $16 . I X .1998$ & Miettinen & O.M. 445 \\
4 & Kn: Kuhmo, Jauhovaara & $7101: 604$ & $4 . X .1998$ & Miettinen & O.M. 653 \\
5 & Kn: Kuhmo, Jauhovaara & $7101: 604$ & $4 . X .1998$ & Miettinen & O.M. 660 \\
\hline
\end{tabular}

\section{Polyporus pseudobetulinus}

\begin{tabular}{cccccc}
\hline Tree no & Collecting site & Coordinate & Collecting date & Collectors & $\begin{array}{c}\text { Preserved } \\
\text { specimens }\end{array}$ \\
\hline 1 & PH: Pihtipudas, Alvajärvi & $7033: 411$ & 1996 & Perälä & JYV \\
2 & PK: Valtimo & $707: 58$ & 14. VIII.1997 & Korhonen & H \\
3 & PK: Lieksa, Saarvavaara & $7063: 633$ & 12. VII.1992 & Sorvari, Ikonen & H \\
4 & PK: Lieksa, Juurikkavaara & $7022: 665$ & 29. VII.1992 & Sorvari & H \\
5 & PK: Nurmes, Uuronvaara & $7086: 632$ & 28. VII.1992 & Tynkkynen & no \\
6 & PK: Nurmes, Louhivaara & $7088: 631$ & 28. VII.1992 & Tynkkynen & H
\end{tabular}


PK: Nurmes, Paistinvaara PK: Ilomantsi, Korpi-Pampalo PK: Ilomantsi, Lakonjärvi SW $\mathrm{Kn}$ : Sotkamo, Heinävaara $\mathrm{Kn}$ : Sotkamo, Heinävaara Kn: Sotkamo, Heinävaara Kn: Sotkamo, Heinävaara Kn: Sotkamo, Heinävaara Kn: Sotkamo, Heinävaara $\mathrm{Kn}$ : Sotkamo, Heinävaara Kn: Sotkamo, Heinävaara $\mathrm{Kn}$ : Sotkamo, Heinävaara Kn: Sotkamo, Heinävaara Kn: Sotkamo, Heinävaara Kn: Sotkamo, Heinävaara Kn: Sotkamo, Heinävaara $\mathrm{Kn}$ : Sotkamo, Heinävaara Kn: Sotkamo, Heinävaara $\mathrm{Kn}$ : Sotkamo, Heinävaara Kn: Sotkamo, Heinävaara Kn: Sotkamo, Heinävaara Kn: Sotkamo, Heinävaara Kn: Sotkamo, Sammakkomäki Kn: Sotkamo, Niemilehto $\mathrm{Kn}$ : Sotkamo, Porkkasalo Kn: Hyrynsalmi, Pölhövaara Kn: Hyrynsalmi, Pölhövaara

$\mathrm{Kn}$ : Suomussalmi, Kankivaara

Ks: Taivalkoski, Kylmävaara

Ks: Kuusamo, Vasikkavaara

Ks: Kuusamo, Visavaara

OP: Pudasjärvi, Haapomaa

PeP: Rovaniemen mlk., Lomalampi 7367:419

PeP: Rovaniemen mlk., Rantakivalo 7385:462

PeP: Rovaniemen mlk., Tuiskukivalo 7343:454

PeP: Rovaniemen mlk., Tuiskukivalo 7343:454

PeP: Rovaniemen mlk., Pisavaara 7353:414

PeP: Rovaniemen mlk. / Tervola, Pisavaara

PeP: Rovaniemen mlk. / Tervola, Pisavaara

$7353: 413$

$7353: 413$
7.XI.1993

16.VIII.1996

16.VIII.1996

2.VII.1999

6.VII. 1999

6.VII.1999

13.VII.1999

23. VII. 1999

31.VIII.1998

31.VIII. 1998

2.IX.1998

2.IX.1998

2.IX.1998

2.IX.1998

2.IX.1998

3.IX.1998

4.IX.1998

4.IX.1998

9.IX.1998

9.IX. 1998

12.VII.1999 1999

11.IX.1998

11.IX.1998

16.\&30.VI.1992

1.VIII.1994

1.VIII.1994

11.VIII.1993

13.X.1996

27.VI.1995

29.VII.1993

28.X.1994

9.VII.1993

28. VIII. 1993

12.X.1995

1996

1996

20.VIII. 1987

29.VII.1979

29.VII.1979, 7.IX.1982

Nissinen
Bondartseva, Lositskaya
Bondartseva, Lositskaya
Penttilä et al.
Penttilä et al.
Penttilä et al.
Penttilä et al.
Penttilä et al.
Penttilä et al.
Penttilä et al.
Penttilä et al.
Penttilä et al.
Penttilä et al.
Penttilä et al.
Penttilä et al.
Penttilä et al.
Penttilä et al.
Penttilä et al.
Penttilä et al.
Penttilä et al.
Penttilä et al.
Penttilä et al.
Juntunen
Juntunen
Koivisto, Sauso
Soppela
Soppela
Karjalainen
Ohenoja
Soppela
Nissinen
Karp
Kokkonen
Ollila
Hiltunen
Martikainen
Martikainen
Kotiranta

Niemelä, Kotiranta

Niemelä, Kotiranta

Kotiranta

Kotiranta

Kotiranta

Kotiranta

Kotiranta

Kotiranta H.K. 4153, 6461, H

Kotiranta no

Kotiranta

$\mathrm{H}$

$\mathrm{H}$

no

no

no

no

no

no

no

no

no

no

no

no

no

no

no

no

no

no

no

no

$\mathrm{H}$

no

$\mathrm{H}$

H, OULU

$\mathrm{H}$

no

no

no

$\mathrm{H}$

no

no

no

H.K. 6472

no

T.N. 1524 , 1525 ,

H.K. 18,4147 , 4148

H.K. 6459

HK 6458, HPP no

H.K. 6473

no
7.IX.1982, 18.VIII. 1987

$\begin{array}{ll}7353: 414 & 24 . \text { VIII. } 1988 \\ 7353: 413 & \text { 5.IX.1989 }\end{array}$ Pisavaara 